\title{
Excisions of 4 unerupted canines in the mentonian region of the mandible - kisses teeth
}

Ricardo Eugenio Varela Ayres de Melo ${ }^{a}$, Marcela Côrte Real Fernandes ${ }^{b}$, Rodrigo Henrique Mello Varela Ayres de Meloc, Milena Mello Varela Ayres de Melo Pinheiro ${ }^{d}$, Victor Leonardo Mello Varela Ayres de Melo ${ }^{e}$, Camilla Siqueira de Aguiar ${ }^{f}$

\begin{abstract}
OBJECTIVE: Unerupted tooth, also called impacted tooth by some authors, is a dental organ that, even when fully developed did not erupt at the regular time, lying inside the bone completely surrounded by bone tissue or bone and mucosal tissue. The unerupted canines study is very important in dentistry, since successful results depend on early diagnosis for proper treatment management, however, despite the importance of this issue, few studies were found in the literature. CASE DESCRPTION: This paper reported a clinical case of a 14-year-old female patient who had four canines in the mentonian region of the mandible surrounded by a dentigerous cyst. The patient underwent a surgical procedure under general anesthesia for the teeth and dentigerous cyst removal.
\end{abstract}

Keywords: unerupted tooth; impacted tooth; oral surgical procedures.

\section{Exodontia de 4 caninos não erupcionados da região mentoniana}

\section{RESUMO}

OBJETIVO: O dente não irrompido, também chamado de dente impactado por alguns autores, é um órgão dental que, mesmo quando totalmente desenvolvido, não entrou em erupção no tempo regular, encontrando-se completamente envolto por tecido ósseo ou tecido ósseo e mucoso. O estudo dos caninos não irrompidos é muito importante na odontologia, pois os resultados de tratamento bem-sucedidos dependem do diagnóstico precoce para o manejo adequado, entretanto, apesar da importância desse problema, poucos estudos foram encontrados na literatura.

DESCRIÇÃO DO CASO: Este trabalho relatou um caso clínico de uma paciente de 14 anos de idade que tinha quatro caninos na região mentoniana da mandíbula coberta por um cisto dentígero. O paciente foi submetido a procedimento cirúrgico sob anestesia geral para os dentes e remoção do cisto.

Palavras-chave: dente não irrompido; dente impactado; procedimentos cirúrgicos orais.

\author{
${ }^{a}$ Coordinator of the Specialization Course in \\ Maxillofacial Surgery and Traumatology of the \\ Federal University of Pernambuco (UFPE), Recife, \\ Brazil \\ ${ }^{\mathrm{b}}$ Dental Surgeon, Recife, Brazil \\ ${ }^{c}$ General Surgeon, Physician, Recife, Brazil \\ d Physiotherapist. Trainee at the Maxillofacial \\ Surgery and Traumatology Ambulatory of the \\ Federal University of Pernambuco (UFPE), Recife, \\ Brazil \\ e Undergraduate Dentistry student of Maurício \\ de Nassau University, Trainee at the Ambulatory \\ of Maxillofacial Surgery and Traumatology of the \\ Federal University of Pernambuco (UFPE), Recife, \\ Brazil \\ ${ }^{\dagger}$ Undergraduate Dentistry student of the Federal \\ University of Pernambuco (UFPE), Trainee at \\ the Ambulatory of Maxillofacial Surgery and \\ Traumatology of the Federal University of \\ Pernambuco, Recife Brazil
}

Conflict of Interests: The authors state that there are no financial and personal conflicts of interest that could have inappropriately influenced their work.

Copyright: @ 2018 de Melo et al.; licensee EDIPUCRS

This work is licensed under a Creative Commons Attribution 4.0 International License. 


\section{INTRODUCTION}

In the human dentition, maxillary and mandibular canines, when present in their normal position, are important both from the aesthetic and functional perspectives. However, included permanent canines occur in a relatively common way and are gradually being documented in the literature $[1,11]$.

Unerupted tooth, also called impacted tooth by some authors, is a dental organ that, even fully developed, did not erupt at the normal time, being inside of the bone and totally surrounded by bone tissue or by bone and mucous tissue [7].

The long and complex eruption pathway of the superior canine takes twice as long to complete its eruption when compared to other dental elements, thus becoming more susceptible to change throughout the eruption trajectory from odontogenesis to the normal occlusion establishment, resulting in eruption or impaction on either vestibular or palatine face [13].

The most frequent uneruptions occur on usually latererupted teeth. As the permanent teeth emerge, the jaws development allows their alignment in the arch. When this development is not enough, teeth become excessively close together, oblique, on an inadequate position or, therefore, remain unerupted. The lack of space in the arch is therefore the main cause of uneruption, therefore impacted third molars and canines are usually bilateral [9].

The frequency of impacted teeth for Freitas; Marin (2006) [7] appears in the following order: (1) Lower third molars; (2) Upper third molars; (3) Upper canines; (4) Lower canines; (5) Upper premolars; (6) Lower premolars; (7) Incisors; (8) First and second molars. However, according to Cunha et al. (2011) [4], except for the third molars that occur in $1 \%$ to $3 \%$ of the population, the permanent maxillary canine is the most prevalent impacted tooth, in consonance with Crozariol; Habitante (2003) [3], who carried out a study aiming to observe the prevalence of unerupted canines and molars in the Department of Dentistry of Taubaté University where they found $1.08 \%$ of canines and $0.76 \%$ of third molars impacted.

According to Sharma; Raghavan; Kumari (2014) [15], the term "Kissing Mandibular Canines" refers to a very original position of impacted lower canines where their vestibular surfaces are in contact in a single follicular space where roots point towards opposite directions in the midline, characterizing an extremely rare condition.

Impaction of canines is ten times more common in the maxilla than in mandible, mostly presenting unilateral tendency besides it is three times more common in females, and its incidence in the population ranges from $1 \%$ to $2 \%$, being more frequent in palatine than vestibular [12]. However, according to Tormena Junior et al. (2004) [16], retentions in the mandible are more common through vestibular.

Some authors speculate about the causes of mandibular canine impaction and transmigration, such as: traumatic factors, lack of space, long eruption pathway of the canine tooth germ, premature loss of deciduous dentition, crown abnormal length, hereditary factors, functional disorders of endocrine glands, tumors and odontomas. In such cases, surgical removal is indicated due to the possible association with pathological lesions, infection, injury to neighbouring teeth, pain, ectopic eruption and interference with prostheses [11].

A better prognosis of impacted teeth may be attained when such condition is early diagnosed [6]. Once achieving better diagnosis requires a well-proceeded anamnesis, evaluating the complaint of the patient along with the signs and symptoms that an even tooth can provoke is essential. At the physical examination, the vestibular or palatine projection may be observed, and the imaging screening is prime to evaluate the relation of the element with adjacent structures [7].

According to Pereira et al. (2012) [14], the main clinical findings to diagnose the presence of impacted canines are: delayed eruption after 14 years old, prolonged retention of a primary canine, elevation of the palate or labial mucosa and crown distally migrations from lateral incisors with or without midline deviation.

The preservation of these impacted elements could create complications such as: reduction of mandible bone tissue, increased prevalence of mandibular fractures, resorption of adjacent tooth roots, local pain and pathological changes [5].

Many unerupted canines present with a well-developed pericoronal follicle, which is radiographically visualized as a radiolucent area around the dental crown. However, these follicles can originate dentigerous cysts which are the most common type of odontogenic developmental cyst and are characterized by a lesion that originates from the separation of the follicle surrounding the crown of an impacted tooth [10,13]. According to Costa et al. (2011) [2], dentigerous cysts are more frequently associated with lower third molars, followed by upper canines and upper third molars, respectively.

The correct diagnosis of impacted teeth is determinant for the choice and success of the proposed treatment. According to Gaetti-Jardima et al. (2012) [8], the location where the canine remains unerupted and the causes of such impaction determine the treatment choice as well as its success. For the authors, the treatment options adopted for unerupted teeth are basically divided into three groups: 1) non-surgical conservative treatments, aiming at the maintenance of the dental element without any surgical approach; 2) the nonconservative ones, which consist in their elimination by exodontic surgical techniques; and 3) conservative surgical or surgical conservatives ones, which aim at the maintenance of the retained tooth, however its exposition to surgical trauma is necessary.

This article aims to report a clinical case of diagnosed unerupted lower canines associated with two other supernumerary teeth that, radiographically and clinically, have similar characteristics to canines surrounded by a dentigerous cyst. 


\section{CASE DESCRIPTION}

J.S.S., a 14-year-old female melanodermic patient, attended the Oral and Maxillofacial Surgery and Traumatology Service of the Federal University of Pernambuco, reporting mentonian discomfort, thus an imaging-based screening was requested. Throughout the anamnesis the patient reported absence of bilateral lower canines as well as absence of traumatic factors to this region and deciduous elements premature loss. No extra-oral findings were detected at extra-oral clinical examination. At the intraoral clinical examination, the patient presented with a discrete volume increase in the mandibular symphysis region, with no alterations in the surrounding mucous membranes, absence of bilateral lower canines and absence of pain sensitivity, therefore the clinical case was a radiographic finding. The imaging-based screening revealed radiopaque images in the symphysis region of the mandible, compatible with unerupted teeth associated with a radiolucent image, suggesting a dentigerous cyst (Figure 1). Due to the extension of the lesion, the chosen treatment was surgery under general anesthesia in order to remove the lesion and exertion of the third molars by orthodontic indication.

Firstly, incisions were performed in both right and left parassinphyseal regions of the mandible, followed by displacements of mucoperiosteal flaps, osteotomies and ostectomies to approach the lesion (Figure 2). Then, aided by Seldin elevators, the uppermost elements on the right side were removed by means of lever points, and afterwards the left side was carefully managed in order not to injure the adjacent elements roots. Also, it could generate space for lower left and right sides removal, located in the basilar region of the mandible, respectively (Figure 3). As a result, the lesion involving the unerupted teeth was carefully removed through curettage so as not to damage the lower alveolar nerve vascular bundle, and this lesion was sent to perform the histopathological screening at the Oral Histopathology Laboratory of the Federal University of Pernambuco. The surgical sequence continued with cavity cleaning and bone regularization (Figure 4), repositioning the flaps and sutures with separate points through 5.0 mononylon wire.

Over the postoperative period, the patient evolved without philogistic signs and after 1 year another facial (panoramic) radiography was requested for post-surgical control. Radiographically, the bone tissue healing in the region was observed, preserving the root apices of the inferior elements (Figure 5). Clinically, the patient presented with preserved tissues and all dental elements demonstrated pulp vitality.

The histopathological report performed by the Oral Histopathology Laboratory of the Federal University of Pernambuco identified a dentigerous cyst. Microscopically, a pathological cavity covered by stratified squamous epithelium was observed, with an adjacent fibrous connective tissue capsule (Figure 6).

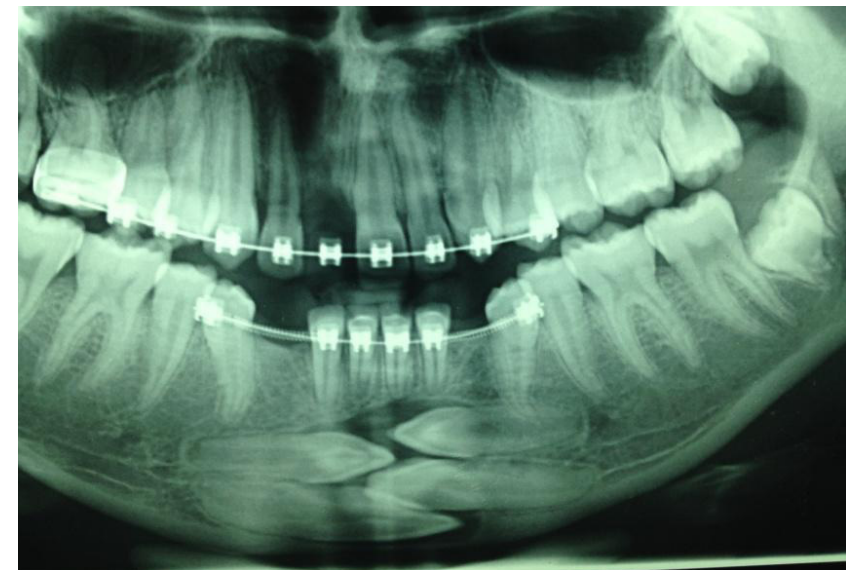

Figure 1. Panoramic radiography exhibiting radiopaque elements in the symphysis region of the mandible, similar to the unerupted teeth, involved by radiolucent image.

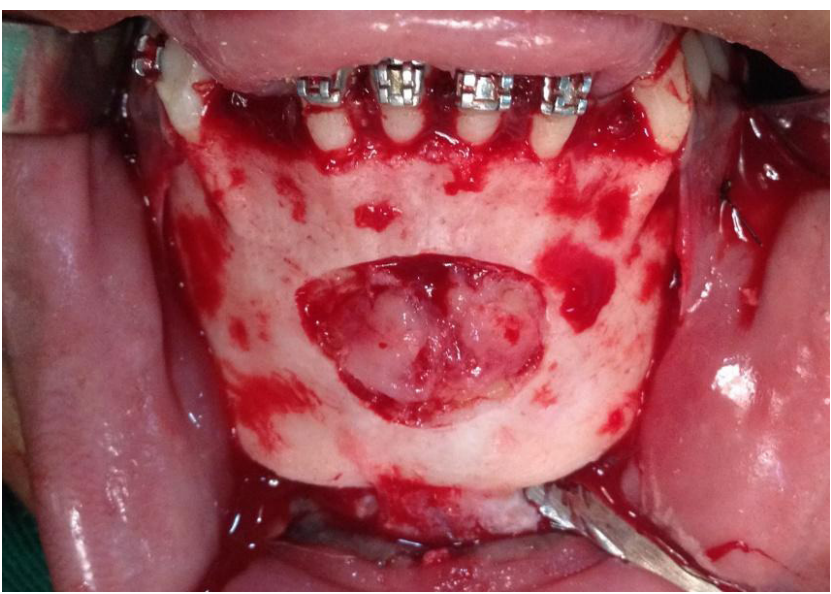

Figure 2. Newmann incision in the right and left parassinphyseal region, with detachment of the mucoperiosteal flap, followed by osteotomies and ostectomies.

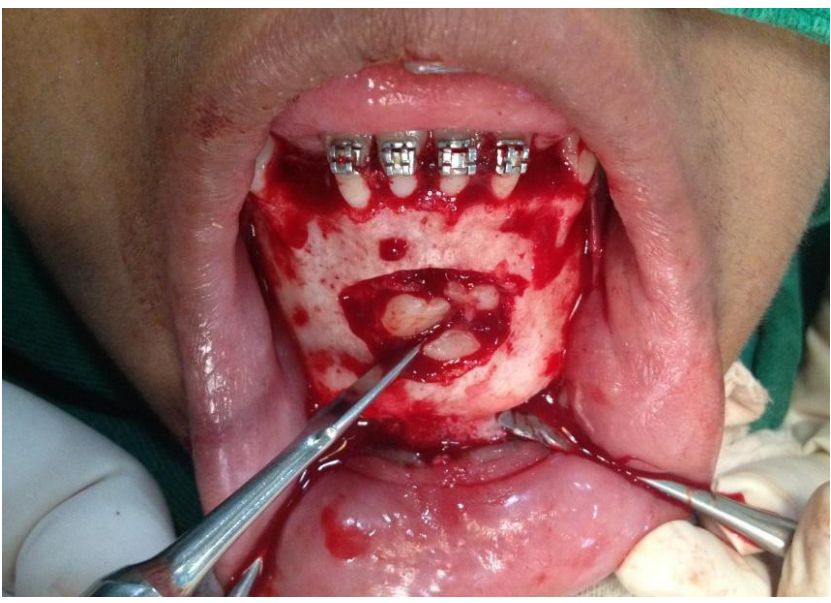

Figure 3. Exertions of impacted teeth aided by Seldin elevators, through lever points. 


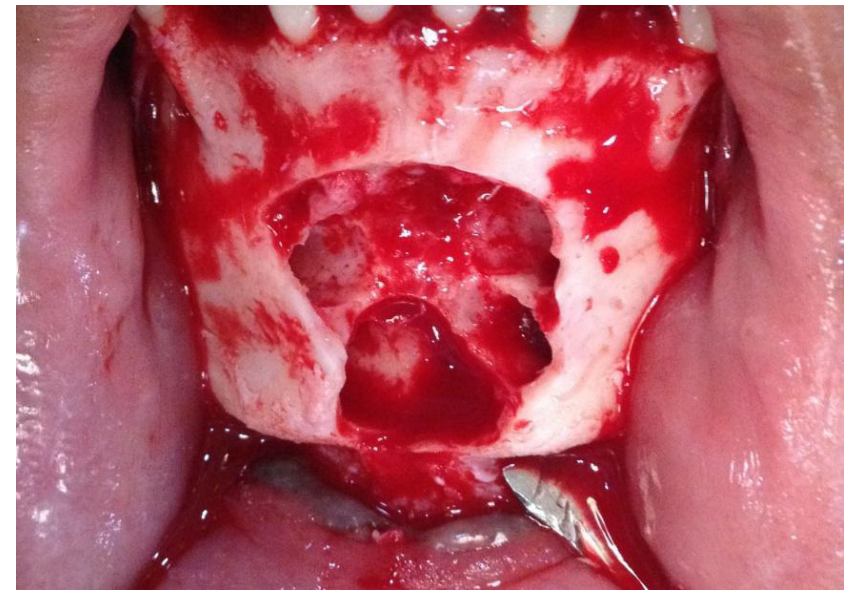

Figure 4. Cystic enucleation with cavity cleaning and bone regularization.

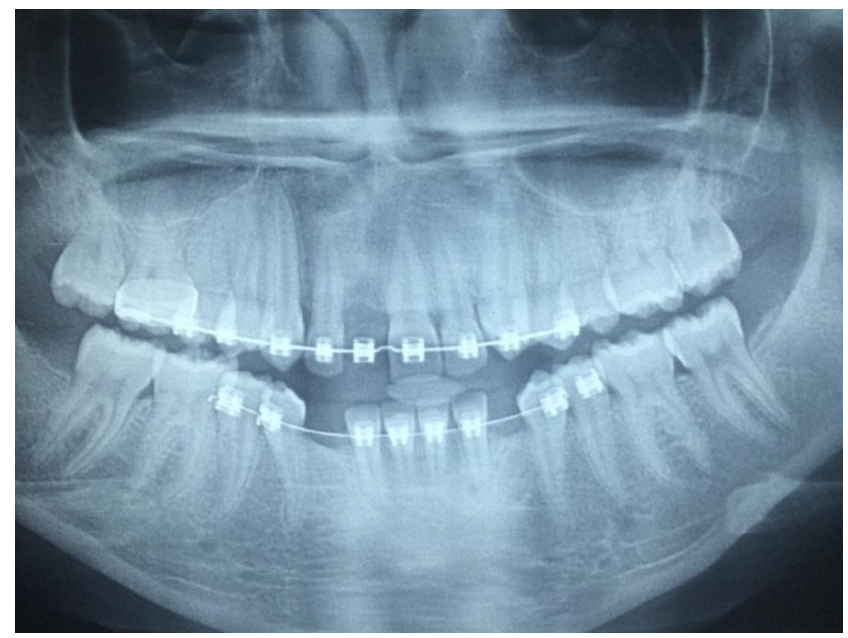

Figure 5. Radiography after 1 year of surgery, exhibiting the mental region healing with the preservation of the root tips of the lower elements.

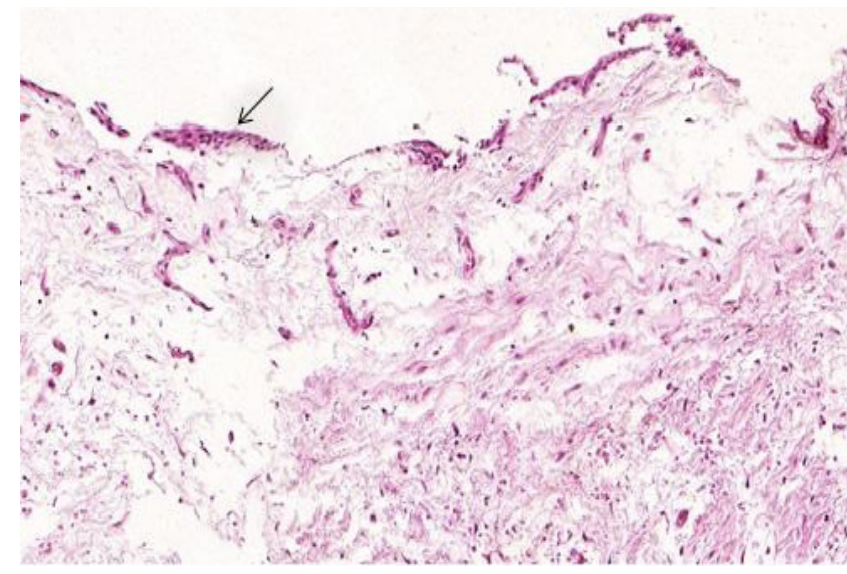

Figure 6. Cystic cavity by stratified squamous epithelium (arrow). Adjacent fibrous connective tissue capsule without inflammation (HE 1X20).

\section{DISCUSSION}

The correct and early diagnosis of impacted teeth is determinant for the choice and success of the proposed treatment. According to Gaetti-Jardima et al. (2012) [8] some factors such as the location of the unerupted canine and the causes of impaction, may imply the success and choice of treatment. In the reported case, the removal of the dental elements was surgically performed given the impossibility of impacted elements exploitation. The clinical case ratifies the abovementioned authors, especially when they mention that mandibular canines horizontally impacted suffer transmigration phenomenon, which consists in their displacement from their original place to the opposite side, thus crossing the dental arch midline so their utilization in such cases become impracticable, therefore extraction should be the best option.

Once the dental elements excision was treatment of choice, the authors Dhuvad; Kshirsagar (2015) [5] reinforce this choice when they affirm that the preservation of these teeth could create complications such as: reduction of mandible bone tissue, increased prevalence of mandibular fractures, resorption of adjacent tooth roots, local pain and pathological changes.

According to Farias et al. (2003) [6] and Freitas; Marin (2006) [7], the prevalence of unerupted teeth occurs more frequently in lower third molars, with lower canines in fourth position. Agarwal et al. (2013) [1], Crozariol; Habitant (2003) [3] and Cunha et al. (2011) [4] reported the highest incidence in upper canines. Maahs; Berthold (2004) [12] stated that canine impaction is ten times more common in the maxilla than in the mandible. The case reported here, however, is unusual because the demographic data do not coincide with those presented in the literature, since the included elements are the lower canines associated with supernumerary teeth, which presented with their normal size, with no association of traumas in the region and without loss of early deciduous elements, which also differs from the authors Hyppolito et al. (2011) [11].

As it is a rare phenomenon, the term "Kissing Mandibular Canines" is cited by Sharma; Raghavan; Kumari (2014) [15] to explain a very original position of impacted lower canines where their vestibular surfaces are in contact in a single follicular space where roots point towards opposite directions in the midline, characterizing an extremely rare condition. Our study is in consonance with the authors, since they presented studies suggesting the transmigration of canines as a rare phenomenon, with prevalence rate of only $0.31 \%$.

According to Graziani (1976) [9], the lack of space in the arcade stands as the main cause of uneruption, whereas according to Tormenta Junior et al. (2004) [16] several problems are associated with impacted teeth, such as vestibular or lingual inclination of these teeth; Infection of the retentions, resulting in pain and trismus; Emergence of a dentigerous cyst; Reabsorption of the impacted tooth and finally the most common concern: root resorption of 
the neighboring teeth. In the case reported, the horizontal position of the dental elements and the presence of a dentigerous cyst contributed to the retention of the teeth, which culminated in the choice of treatment, being assured by Pereira et al. (2012) [14], who affirmed that impacted canine removal is recommended when it presents with an inclination equal to or greater than 45 degrees as well as when it is close to the midline and adjacent teeth roots.

According to Neville et al. (2009) [13] dentigerous cysts typically present with a unilocular radiolucent area in radiographic screening that is associated with the crown of an impacted tooth. According to Costa et al. (2011) [2] and Gonzalez et al. (2011) [10], this lesion is associated with lower third molars, followed by upper canines. The radiographic aspect presented in our case report differs from the most common aspect above mentioned, since the lesion comprised four dental elements, reaching larger proportions than the most common one. In addition, the dentigerous cyst presented with a rare condition, as it was associated with impacted bilateral and supernumerary lower canines.

\section{CONCLUSION}

Due to this rare clinical occurrence, canines impacted in the mentonian region are less discussed in literature when compared to impacted upper canines given their lower incidence rates.

This case reported a situation where the lower canines were impacted, together with supernumerary dental elements involved by a single dentigerous cyst. "Kisses teeth" term specifies the atypical position of the elements where they meet the vestibular surfaces, being in contact to each other in a single follicular space and with roots pointing towards opposite directions in the mandibular midline region. The dentigerous cyst covers all elements, crossing the median line which characterizes another usual variant form, because it involves multiple dental elements. This fact becomes important, both for surgical, pathological and radiological professionals, being the accomplishment of the correct diagnosis extremely important.

\section{REFERENCES}

1. Agarwal S, Yadav S, Shah NV, Valiathan A, Uribe F, Nanda R. Correction of bilateral impacted mandibular canines with a lip bumper for anchorage reinforcement. American Journal Of Orthodontics And Dentofacial Orthopedics 2013;143:393-403

2. Costa DD, Maia CC, Ribeiro LSF, Falcão AFP. Cisto dentígero associado a canino incluso em maxila. Clipeodonto: UNITAU 2011;3:32-6.

3. Crozariol S, Habitante SM. Prevalência de Caninos e Molares Inclusos e sua Relação com a Reabsorção Radicular. Rev. Biociênc 2003;9:55-60.

4. Cunha CI, Polleto CAR, Icnácio AS, Guariza O, Tanala O, Camargo ES. Associação entre caninos inclusos e agenesias de incisivos laterais superiores permanentes. Arch Oral Res 2011;7:147-55.

5. Dhuvad JM, Kshirsagar RA. Impacted love: mandibular kissing molars advisable to remove or not. J Clin Diagn Res 2015:9:1. https://doi. org/10.7860/JCDR/2015/11226.5384

6. Farias JG, Santos FP, Campos PSF, Sarmento VA, Barreto S, Rios V. Prevalência de Dentes Inclusos em Pacientes Atendidos na Disciplina de Cirurgia do Curso de Odontologia da Universidade Estadual de Feira de Santana. Pesq Bras Odontoped Clin Integr 2003;3:15-9.

7. Freitas R, Marin JLS. Cirurgia dos Dentes Inclusos. In: FREITAS, R. Tratado de Cirurgia Bucomaxilofacial. São Paulo: Santos, 2006. Cap. 10, p. $151-84$

8. Gaetti-Jardima EC et al. Condutas Terapêuticas para Caninos Inclusos Unopar Cient Ciênc Biol Saúde 2012;14:51-6.

9. Graziani M. Cirurgia dos Dentes Inclusos. In: GRAZIANI, Mario. Cirurgia Buco-Maxilo-Facial. 6a ed. São Paulo: Guanabara Koogan, 1976. Cap. 12, p. 222-62.

10. Gonzalez SM, Spalding PM, Payne JB, Giannini PJ. A dentigerous cyst associated with bilaterally impacted mandibular canines in a girl: a case report. J Med Case Reports 2011;230:1-4. https://doi.org/10.1186/17521947-5-230

11. Hyppolito JOP, Paies MB, Veras-Filho RO, Florian F, Hochuli-Vieira E. Tratamento cirúrgico de canino incluso em mento: relato de caso. Rev Odontol Unesp 2011;40:42-6.

12. Maahs MAP, Berthold TB. Etiologia, diagnóstico e tratamento de caninos superiores permanentes impactados. R. Ci. Méd. Biol 2004;3:130-8.

13. Neville BW, Damm DD, Allen CM, Bouquot JE. Patologia das Glândulas Salivares. In: Neville BW, Damm DD, Allen CM, Bouquot JE. Patologia Oral e Maxilofacial. 3a ed. Rio de Janeiro: Elsevier, 2009. Cap. 15, p. 680-3.

14. Pereira CCS, Jardim ECG, Carvalho ACGS, Gealh WC, Cursino NM Garcia IRG. Surgical-Orthodontic Traction for Impacted Maxillary Canines: A Critical Review and Suggested Protocol. Stomatos 2012;18:78-83.

15. Sharma S, Raghavan V, Kumari S. Kissing mandibular canines: Serendipity at its best .J Indian Acad Oral Med Radiol 2014;26:82-4. https://doi. org/10.4103/0972-1363.141867

16. Tormena Junior R, Vedovello M, Ramalho SA; Wassall T, Valdrighi HC Caninos Superiores Retidos: uma Reabilitação Estética e Funcional. J Bras Ortodon Ortop Facial 2004;49:77-86. 